\title{
New model for the selection of effective wall solutions for residential buildings
}

\author{
Jolanta Tamošaitiené ${ }^{1}$, Tomas Starta ${ }^{2}$ \\ Faculty of Civil Engineering, Vilnius Gediminas Technical University, Vilnius, Lithuania
}

E-mail: 'jolanta.tamosaitiene@vgtu.lt (corresponding author)

\begin{abstract}
Currently, the construction sector is facing requirements for higher quality and efficiency standards as well as objectives related to value creation. In construction, rational decision-making problems often involve creating a unique complex of criteria, which must consider multiple requirements and conditions. The paper presents the developed model for the selection of multi-layered external walls of a residential building. The model considers the following aspects and parameters: time, cost, quality, environmental conditions, aspects of sustainable development, and problemsolving benefits received from the assessment of alternatives and the development of the model. Game theory was used to calculate the defining rational decision. For the calculations was used game theory: Bayes, Wald's rule, Savage criterion, Laplace's rule. This study presents the developed model for the selection of multi-layered external walls of a residential building and calculation results based on game-theory rules, which are effective tools for rational decisionmaking.
\end{abstract}

Keywords: time, cost, quality, game theory, rational decisions.

\section{Introduction}

Every year, Lithuania sees increasing numbers of residential buildings. The growing economy results in higher quality standards and environmental requirements in the construction sector. A wide variety of options available on the market makes it complicated to choose construction materials that not only meet requirements related to cost-effectiveness but also ecology. Therefore, the thorough and professional selection of an optimal building-installation time, price, thermal insulation system, ecology and sustainability represents one of the most important technical and economic aims. The selection of an effective option of external building walls from among a vast number of alternatives is an important problem in project management. Construction and operational expenses depend on the effectiveness of the selected external wall solution. The selection should be based on established requirements and aims that extend until the endof-life of a building. Clients want to minimise the likely costs of the project, but they also want to achieve the highest acceptable quality standards and satisfy technological, architectural, and comfort requirements. Other participants of the construction process are interested in maximising profits; and they are also concerned with other attributes, such as company growth, market share, and interests of state institutions (Medineckienė, Turskis, Zavadskas, \& Tamošaitienè, 2010; Medineckienè, Turskis, Zavadskas, \& Folke, 2015). All decisions involve choosing one alternative from several. In the case of this article, thirteen alternatives were compared. A feasible solution can be determined according to established attributes employing the process of multiple-attribute optimisation. External wall alternatives can be evaluated using the available multiple-attribute methods. This paper presents the game theory methodology that allows a decision maker to reach a decision by designing external wall alternatives and evaluating qualitative and quantitative attributes in the process.

\section{Literature review}

Numerous articles analyse options available for the selection of the best material or technology, and different comparative methods have been used to determine results. The most rational and effective solution in terms of materials and technologies has been selected using assessment methods and different quantitative and qualitative techniques. The literature offers wide discussions regarding the comparative analysis, and almost every field or subject can be linked to equilibrium analysis calculations and decision making. 
Game theory is among the most efficient tools that can be used to investigate such issues (Peldschus, 2008). To ensure effective selection of materials, different decision-makers must be involved at various stages; besides, many aspects - such as costs, time, heat transfer, strength, and the ecology - must be considered. Consequently, game theory is required to define and interpret the behaviour of different parties involved in the system. In every decision-making, the most common issue is that nothing can be described and expressed using one quantity or indicator as it is difficult to discern a property that combines all of the essential aspects. Therefore, the results obtained using the game theory approach are different from the results received by applying a traditional optimisation method. Game theory provides a framework for evaluating the effects of individual actions by decision-makers on the project result to develop a more extensive satisfactory solution. However, game theory has not been widely used in the selection of construction materials.

\section{The buildings structural selection problem}

Construction is one of the most important and complicated areas of economic activity that plays a significant role in the social and economic life of people and the whole country. The scale of different types of construction projects reflects the national economic situation. In the past, shapes of buildings and structural solutions were determined by the available building materials and technologies. Consequently, their development dictated construction trends and offered more opportunities and alternatives. At the same time, architectural, structural and quality requirements evolved (Zavadskas, Šimkus, Sakalauskas, \& Nakas, 2000; Zavadskas, Kaklauskas, Turskis, \& Tamošaitienė, 2008). The diversity of building materials and types of construction, the expanding real estate market and the needs of people demand new structural solutions and their assessment methods as well as enhanced knowledge on the condition of buildings and their structures (Zavadskas et al., 2006). Structures of the same purpose can be made of different materials, so it is crucial to be able to choose the most rational products and solutions. The range of structural elements necessitates customers, architects and engineers to continuously expand their knowledge and allows to choose rational solutions depending on different needs. In practice, a decision maker often has to choose one of the best several options or possible alternatives. However, none of them can be described and expressed using a single quantity or indicator as it is difficult to discern a property that combines all of the essential aspects of a required solution. As a result, a variety of available assessment methods are used.

An analysis of the best structural solution or material can be made using game theory. Game theory depends on groups of operational research methods. Various classifications of operational research methods have been proposed by different authors; however, no unified classification exists. Moreover, operational research methods include matching groups: MCDM - Multi-Criteria Decision Making, MADM - Multi-Attribute Decision-Making Methods, MODM - Multi-Objective Decision-Making Methods, game theory, etc. In the case of single objective optimisation problems, it is considered that MCDM methods enhance rationality. Game theory can recognise and clarify the behaviours of project parties in the case of problems and describe how interactions of different stakeholders, such as clients, main contractors or subcontractors, can move a project forward. Game theory and optimisation methods often produce different results. In optimisation methods, all parties are willing to act, which can lead to the best results for the whole system; while in game theory, each party tends to act individually, which can lead to the most logical outcome for that party and not necessarily the best result for the whole system (Barough, Shoubi, \& Skardi, 2012).

Also, extensive research exists regarding the selection of the best solution or technology using a multi-criteria method. Multiple-criteria decision-making or multiple-criteria decision analysis is a sub-discipline of operations research that explicitly evaluates multiple conflicting criteria in decision making. Conflicting criteria are distinctive to the evaluation of alternatives: cost or price is usually one of the main criteria, and some measure of quality is typically another criterion, which is usually in conflict with the cost (Madurika \& Hemakumara, 2015).

\section{Developed model of the problem and case study}

The methodology consists of seven main factors (Figure 1). It started with a literature review, which focused on similar studies on broader issues. The literature review helped in setting the key criteria, which was the first step towards the game theory application. The criteria were set considering the most relevant current issues, namely, price, time and sustainability. With all the key criteria in place, it was necessary to determine their significance. The materiality process began with an expert survey, which resulted in the determination of the most and least significant criteria in the view of construction experts. Using the collected data, a primary data table was compiled. These data were calculated using the game theory rules. Game theory was then used employing the following methods: empirical Bayes (Bishop, 2005), Wald's rule (Harrell, 2001), Savage criterion (Savage, 1951), Laplace's rule (MacKay, 2003). The methods were used to determine the usefulness of each $X$ based on the criteria values of the available data. To compare the results of risk assessment of construction objects, the average (Hwang \& Yoon, 1981), Borda (Borda, 1781) and Copeland (Fishburn, 1971) methods were used (Ustinovičius, Zavadskas, \& Podvezko, 2007).

Construction effectiveness in developed model are based on the main criteria: installation time, economic efficiency, cost-effectiveness, quality, sustainability and ecology. To achieve the best results for each of these criteria, 
different building materials should be selected and fully analysed. So, it is crucial to choose the targeted criteria. Criteria that reflect the purpose of the operation must be used when assessing different alternatives. An operation is a system of actions designed to achieve a particular goal. The search for effective wall solutions begins with the selection of alternatives that can be compared with each other according to the chosen criteria. An indicator is a definition of a property of the object in question (time, installation costs, labour costs).

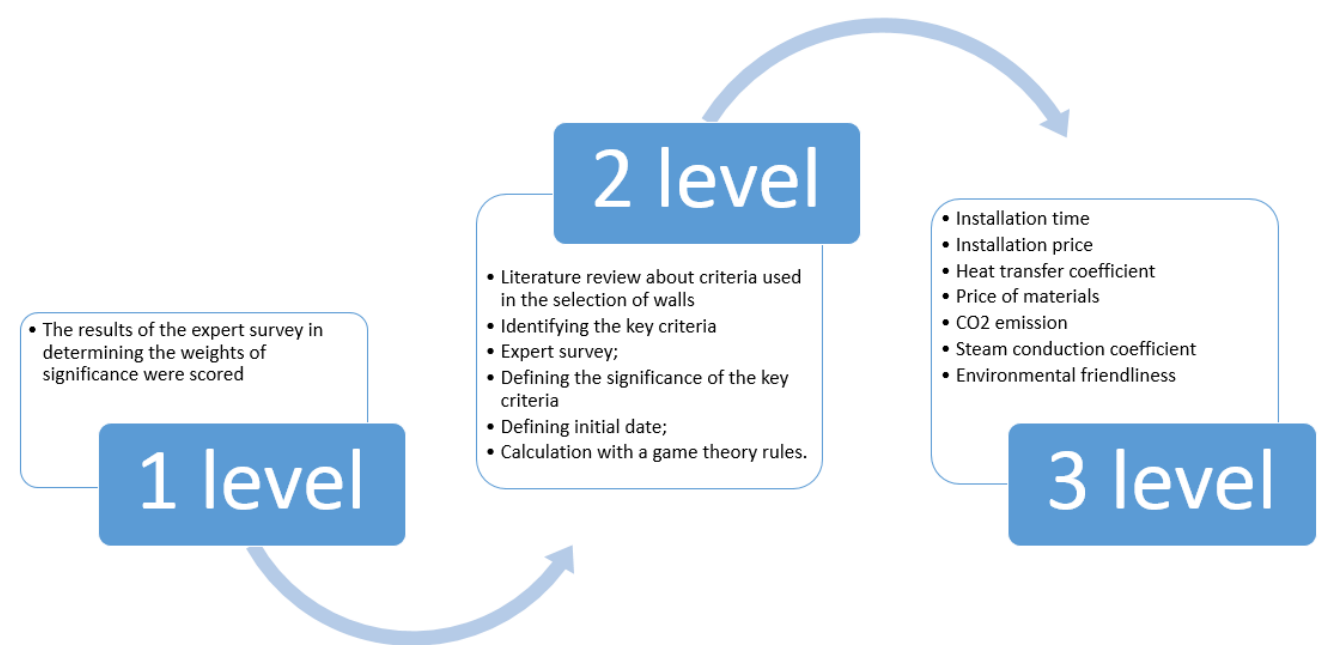

Figure 1. Model of the problem

All of the above criteria could be further elaborated to receive more indicators. The analysis of possible solutions for walls of a building was based on installation time, cost, energy efficiency, cost-effectiveness, sustainability and ecology. It resulted in seven main evaluation indicators (Table 2): installation time, installation price, and heat transfer coefficient, price of materials, $\mathrm{CO}_{2}$ emissions, water vapour permeability coefficient, and environmental friendliness. In the decision matrix, the criteria were grouped into quantitative and qualitative. Quantitative indicators include annual costs, capital inputs, installation costs, profit, profitability, workload per unit of time, and work duration. Qualitative indicators may include aesthetic image, taste, prestige and convenience. The values of each criterion must be known. Quantitative characteristic values are usually determined by calculations, comparing technical, physical, mechanical or other properties, such as thermal resistance, acoustic properties and material strength. Quantitative indicators include price, labour costs and many others, which have their own units of measurement.

Table 1. Evaluation criteria used in the multi-criteria analysis

\begin{tabular}{|c|c|l|c|}
\hline Number & Indicator & Criteria & Units \\
\hline 1 & $x_{1}$ & installation time & hours \\
\hline 2 & $x_{2}$ & installation price & $\mathrm{W} / \mathrm{m}^{2} \mathrm{~K}$ \\
\hline 3 & $x_{3}$ & heat transfer coefficient & $\epsilon / \mathrm{m}^{2}$ \\
\hline 4 & $x_{4}$ & price of materials & $\mathrm{kg} / 100 \mathrm{~m}^{2}$ \\
\hline 5 & $x_{5}$ & $\mathrm{CO}_{2}$ emissions & $\mu$ \\
\hline 6 & $x_{6}$ & water vapour permeability coefficient & points \\
\hline 7 & $x_{7}$ & environmental friendliness & \\
\hline
\end{tabular}

Values of quality characteristics can be determined by experts, recommendations or using sociological, computational and analogue methods (Zavadskas, Peldschus, \& Kaklauskas, 1994). In the case of this study, an expert method was used. Table 1 shows that this study used seven different criteria in the selection of effective wall solutions, five of which were quantitative and two were qualitative. Quantitative indicators were derived from calculations and could be expressed in numerical terms. The qualitative indicator - the environmental friendliness of the materials - was evaluated by experts during the survey.

The evaluation of materiality is among the most important processes in the criteria selection. It allows determining the most and least significant criteria. The significance of the criteria is not an objective assessment as each person evaluates them individually. Therefore, to obtain the most objective information, an expert survey is conducted. Then, the survey data is processed, and the significance of the indicator is determined based on the results. The relevance of the criteria can be determined with sufficient precision using expert survey and statistical methods (Zavadskas, Kaklauskas, \& Banaitienè, 2001). This study used an expert survey. Interviews were conducted with 15 engineers 
representing construction companies. The results of the expert survey are presented in Table 2 . To determine the significance of the indicators, a 7-point scale was used. The most significant indicator could be given the highest score of seven.

Table 2. Results of the expert survey in determining weights of significance in scores

\begin{tabular}{|c|c|c|c|c|c|c|c|c|c|c|c|c|c|c|c|c|}
\hline & 1 & 2 & 3 & 4 & 5 & 6 & 7 & 8 & 9 & 10 & 11 & 12 & 13 & 14 & 15 & SUM \\
\hline$x_{1}$ & 7 & 5 & 3 & 7 & 7 & 7 & 6 & 7 & 4 & 7 & 6 & 5 & 3 & 7 & 4 & 85 \\
\hline$x_{2}$ & 6 & 4 & 5 & 5 & 4 & 6 & 7 & 5 & 7 & 6 & 7 & 7 & 4 & 5 & 6 & 84 \\
\hline$x_{3}$ & 5 & 6 & 4 & 6 & 6 & 5 & 4 & 4 & 6 & 5 & 1 & 1 & 5 & 1 & 7 & 66 \\
\hline$x_{4}$ & 1 & 3 & 6 & 3 & 5 & 2 & 1 & 6 & 5 & 2 & 2 & 6 & 6 & 4 & 5 & 57 \\
\hline$x_{5}$ & 4 & 2 & 2 & 1 & 3 & 4 & 3 & 2 & 1 & 3 & 4 & 3 & 1 & 2 & 1 & 36 \\
\hline$x_{6}$ & 2 & 1 & 1 & 4 & 2 & 3 & 2 & 1 & 3 & 4 & 3 & 2 & 2 & 3 & 3 & 36 \\
\hline$x_{7}$ & 3 & 7 & 7 & 2 & 1 & 1 & 5 & 3 & 2 & 1 & 5 & 4 & 7 & 6 & 2 & 56 \\
\hline
\end{tabular}

The data allows estimating the popularity of each option in percentage. It is important to determine the weights of the indicators using multi-criteria methods. Expert judgment serves as the basis for the calculation of weights. Results are considered practicable in the case of sufficient compatibility of expert opinions. It is determined by the coefficient of concordance, which is calculated based on the ranking of comparable objects. Coefficients of concordance were calculated in this study.

Defined by Kendall (1970), the coefficient of concordance represents the sum $t_{j}$ of the scores given by all experts to each indicator:

$$
t_{j}=\sum_{k=1}^{r} t_{j k},(j=1, \ldots, n),
$$

where $t_{j k}$ - the evaluation of a criterion by an expert, $r$ - the evaluation of a criterion by an expert.

Then, the overall average is

$$
t_{j L}=\frac{\sum_{k=1}^{n} t_{k}}{n},
$$

where $t_{k}-$ the total number of points.

Then, the expert judgment dispersion amounts to

$$
\partial^{2}=\frac{1}{r-1} \sum_{k=1}^{r}\left(t_{j k}-t_{j L}\right)^{2} .
$$

The final indicator for the source data is the size of the variation:

$$
\beta=\frac{\partial}{t_{j}} .
$$

Table 3 shows the data of this study, which can be used to make further calculations and determine whether expert assessments were compatible during the survey.

Table 3. Calculation results

\begin{tabular}{|c|c|c|c|c|c|c|c|}
\hline & $x_{1}$ & $x_{2}$ & $x_{3}$ & $x_{4}$ & $x_{5}$ & $x_{6}$ & $x_{7}$ \\
\hline$t_{j}$ & 85.00 & 84.00 & 66.00 & 57.00 & 36.00 & 36.00 & 56.00 \\
\hline$t_{j L}$ & 5.67 & 5.60 & 4.40 & 3.80 & 2.40 & 2.40 & 3.73 \\
\hline$\partial^{2}$ & 33.33 & 17.60 & 53.60 & 50.40 & 17.60 & 13.60 & 72.93 \\
\hline 6 & 1.02 & 0.75 & 1.66 & 1.87 & 1.75 & 1.54 & 2.29 \\
\hline
\end{tabular}


The data can be used to calculate the average of the amount, which is determined as follows:

$$
V=\frac{1}{r} \sum_{j=1}^{n=7} \sum_{k=1}^{r=15} t_{j k}=\frac{1}{15} * 420=28 .
$$

The average of the amount produces the deviation of the estimate, which amounts to:

$$
S=\sum_{j=1}^{n=7}\left(\sum_{k=1}^{r=15} t_{j k}-V\right)^{2}=(420-28)^{2}=153664 .
$$

This gives us the Coefficient of Coordination:

$$
W=\frac{12 * S}{r^{2}\left(n^{3}-n\right)}=\frac{12 * 153664}{15^{2}\left(7^{3}-7\right)}=24.39 .
$$

The data is then used to calculate the significance of the Concordance Factor:

$$
X^{2}=\frac{12 * S}{r * n(n+1)}=\frac{12 * 153664}{22 * 7(7+1)}=374.18 .
$$

The chosen materiality level $\alpha$ was used to find the critical value $X^{2}$ krit $(0.05 ; 7)=15.21$ for the degree of freedom of $v=n-1$ in section $X^{2}$, which is much less than $X^{2}$. Consequently, expert evaluations were well aligned during this survey.

Based on the selected alternatives and assessment criteria, an initial task table was created specifying the data used for the analysis and evaluation. Thirteen different wall installation alternatives were analysed. All data in Table 4 were collected from reliable sources. The installation time and costs were taken from the Lithuanian requirements for the construction duration, cost estimation requirements. Installation time means how much amount of work can be done per hour. Installation price means the price of works for $1 \mathrm{~m}^{2}$. The heat transfer coefficient was calculated in accordance with the applicable standards to meet the class A thermal resistance and it shows the construction thermal conductivity. The prices of the materials were taken from the information published by sellers online. $\mathrm{CO}_{2}$ emission per ton of material and water vapour permeability coefficient were taken from the FAO Corporate document repository

\begin{tabular}{|c|c|c|c|c|c|c|c|}
\hline \multirow{3}{*}{ Alternative } & \multicolumn{7}{|c|}{ Criteria } \\
\hline & $\begin{array}{l}\text { Installa- } \\
\text { tion time } \\
1 \mathrm{~m}^{2}\end{array}$ & $\begin{array}{l}\text { Installa- } \\
\text { tion price } \\
1 \mathrm{~m}^{2}\end{array}$ & $\begin{array}{c}\text { Heat } \\
\text { transfer } \\
\text { coefficient }\end{array}$ & $\begin{array}{c}\text { Material } \\
\text { price }\end{array}$ & $\begin{array}{l}\mathrm{CO}_{2} \text { emis- } \\
\text { sion per ton } \\
\text { of material }\end{array}$ & $\begin{array}{l}\text { Water vapour } \\
\text { permeability } \\
\text { coefficient }\end{array}$ & $\begin{array}{c}\text { Ecology } \\
\text { of mate- } \\
\text { rials }\end{array}$ \\
\hline & $x_{1}$ & $x_{2}$ & $x_{3}$ & $x_{4}$ & $x_{5}$ & $x_{6}$ & $x_{7}$ \\
\hline Units & hour & $€ /$ hour & $W / m^{2} K$ & $\epsilon / m^{2}$ & $\mathrm{t}$ & $\mu$ & points \\
\hline Importance & 0.20 & 0.20 & 0.16 & 0.14 & 0.08 & 0.09 & 0.13 \\
\hline Direction & $\min$ & $\min$ & $\min$ & $\min$ & $\min$ & $\min$ & $\max$ \\
\hline $\begin{array}{l}\text { Porous concrete blocks and } \\
\text { stone-wool thermal insulation }\end{array}$ & 1.10 & 5.58 & 0.12 & 35 & 0.5 & 6 & 2 \\
\hline $\begin{array}{l}\text { Ceramic blocks and stone- } \\
\text { wool thermal insulation }\end{array}$ & 1.05 & 5.58 & 0.12 & 32 & 0.4 & 16 & 4 \\
\hline $\begin{array}{l}\text { Clay blocks and stone-wool } \\
\text { thermal insulation }\end{array}$ & 0.93 & 5.58 & 0.12 & 37 & 0.4 & 6 & 3 \\
\hline $\begin{array}{l}\text { Silicate blocks and stone- } \\
\text { wool thermal insulation }\end{array}$ & 0.93 & 5.58 & 0.12 & 25 & 0.5 & 6 & 3 \\
\hline $\begin{array}{l}\text { Ceramic bricks and stone- } \\
\text { wool thermal insulation }\end{array}$ & 1.53 & 5.41 & 0.12 & 47 & 0.8 & 16 & 4 \\
\hline $\begin{array}{l}\text { Silicate bricks and stone- } \\
\text { wool thermal insulation }\end{array}$ & 1.60 & 5.41 & 0.12 & 40 & 0.8 & 16 & 3 \\
\hline
\end{tabular}
and it shows the construction vapour coefficient level. The environmental performance of the walls was determined based on the composition of the materials and their environmental impact.

Table 4. Walls alternatives and their evaluation 
End of Table 4

\begin{tabular}{|l|c|c|c|c|c|c|c|}
\hline \multirow{2}{*}{ Alternative } & \multicolumn{7}{|c|}{ Criteria } \\
\cline { 2 - 8 } & $\begin{array}{c}\text { Installa- } \\
\text { tion time } \\
1 \mathrm{~m}^{2}\end{array}$ & $\begin{array}{c}\text { Installa- } \\
\text { tion price } \\
1 \mathrm{~m}^{2}\end{array}$ & $\begin{array}{c}\text { Heat } \\
\text { transfer } \\
\text { coefficient }\end{array}$ & $\begin{array}{c}\text { Material } \\
\text { price }\end{array}$ & $\begin{array}{c}\mathrm{CO}_{2} \text { emis- } \\
\text { sion per ton } \\
\text { of material }\end{array}$ & $\begin{array}{c}\text { Water vapour } \\
\text { permeability } \\
\text { coefficient }\end{array}$ & $\begin{array}{c}\text { Ecology } \\
\text { of mate- } \\
\text { rials }\end{array}$ \\
\cline { 2 - 8 } & $x_{1}$ & $x_{2}$ & $x_{3}$ & $x_{4}$ & $x_{5}$ & $x_{6}$ & $x_{7}$ \\
\hline $\begin{array}{l}\text { Porous concrete blocks and } \\
\text { polystyrene thermal insulation }\end{array}$ & 1.10 & 5.58 & 0.12 & 40 & 1.0 & 35 & 1 \\
\hline $\begin{array}{l}\text { Ceramic blocks and polysty- } \\
\text { rene thermal insulation }\end{array}$ & 1.05 & 5.58 & 0.12 & 34 & 0.9 & 45 & 3 \\
\hline $\begin{array}{l}\text { Ceramic blocks and polysty- } \\
\text { rene thermal insulation }\end{array}$ & 0.93 & 5.58 & 0.12 & 44 & 0.9 & 35 & 2 \\
\hline $\begin{array}{l}\text { Silicate blocks and polysty- } \\
\text { rene thermal insulation }\end{array}$ & 0.93 & 5.58 & 0.12 & 32 & 1.0 & 35 & 2 \\
\hline $\begin{array}{l}\text { Ceramic bricks and polysty- } \\
\text { rene thermal insulation }\end{array}$ & 1.53 & 5.41 & 0.11 & 49 & 1.3 & 45 & 3 \\
\hline $\begin{array}{l}\text { Silicate bricks and polysty- } \\
\text { rene thermal insulation }\end{array}$ & 1.60 & 5.41 & 0.11 & 47 & 1.3 & 45 & 2 \\
\hline $\begin{array}{l}\text { Thermo blocks and polysty- } \\
\text { rene thermal insulation }\end{array}$ & 1.41 & 6.58 & 0.90 & 52 & 1.1 & 30 \\
\hline
\end{tabular}

Following the determination of evaluation criteria and their materiality, data collection was started using the game theory. The information was processed, and the software determined the utilisation factors for each $X$ using linear transformation. The data is given in Table 5.

Table 5. Walls valuations by indicator

\begin{tabular}{|c|c|c|c|c|c|c|c|}
\hline Option & $X_{1}$ & $X_{2}$ & $X_{3}$ & $X_{4}$ & $X_{5}$ & $X_{6}$ & $X_{7}$ \\
\hline 1 & 0.746 & 0.855 & 0.987 & 0.630 & 0.889 & 1.000 & 0.333 \\
\hline 2 & 0.821 & 0.855 & 0.987 & 0.741 & 1.000 & 0.744 & 1.000 \\
\hline 3 & 1.000 & 0.855 & 0.987 & 0.556 & 1.000 & 1.000 & 0.667 \\
\hline 4 & 1.000 & 0.855 & 0.987 & 1.000 & 0.889 & 1.000 & 0.667 \\
\hline 5 & 0.104 & 1.000 & 0.987 & 0.185 & 0.556 & 0.744 & 1.000 \\
\hline 6 & 0.000 & 1.000 & 0.987 & 0.444 & 0.556 & 0.744 & 0.667 \\
\hline 7 & 0.746 & 0.855 & 0.987 & 0.444 & 0.333 & 0.256 & 0.000 \\
\hline 8 & 0.821 & 0.855 & 0.987 & 0.667 & 0.444 & 0.000 & 0.667 \\
\hline 9 & 1.000 & 0.855 & 0.987 & 0.296 & 0.444 & 0.256 & 0.333 \\
\hline 10 & 1.000 & 0.855 & 0.987 & 0.741 & 0.333 & 0.256 & 0.333 \\
\hline 11 & 0.104 & 1.000 & 1.000 & 0.111 & 0.000 & 0.000 & 0.667 \\
\hline 12 & 0.000 & 1.000 & 1.000 & 0.185 & 0.000 & 0.000 & 0.333 \\
\hline 13 & 0.284 & 0.000 & 0.000 & 0.000 & 0.222 & 0.385 & 0.333 \\
\hline
\end{tabular}

To compare the results, a decision-making matrix was created with rows as priorities, calculated using the mentioned methods listed in columns. Then, the matrix $Y$ was created with all columns composed of an option priority row, calculated by an appropriate method, and the additional column composed of members that had added numerical values of the rationality of the alternatives, and dividing them by the number of methods used (Table 6).

According to Table 6, the lowest value of the last column of the matrix $Y$ was the most rational: $X_{13} \succ X_{12} \succ X_{11}$ $\succ X_{6} \succ X_{5} \succ X_{10} \succ X_{7}=X_{8}=X_{9} \succ X_{1}=X_{2}=X_{3} \succ X_{4}$. 
Table 6. Calculation results for minimum values of alternatives

\begin{tabular}{|c|c|c|c|c|c|c|}
\hline Methods & Bayes & Wald's rule & Savage criterion & Laplace's rule & Averages & Overall rating \\
\hline$X_{1}$ & 4 & 2 & 2 & 4 & $\mathbf{3 . 0 0}$ & $\mathbf{2}$ \\
\hline$X_{2}$ & 2 & 4 & 4 & 2 & $\mathbf{3 . 0 0}$ & $\mathbf{2}$ \\
\hline$X_{3}$ & 3 & 3 & 3 & 3 & $\mathbf{3 . 0 0}$ & $\mathbf{2}$ \\
\hline$X_{4}$ & 1 & 1 & 1 & 1 & $\mathbf{1 . 0 0}$ & $\mathbf{1}$ \\
\hline$X_{5}$ & 8 & 9 & 9 & 5 & $\mathbf{7 . 7 5}$ & $\mathbf{5}$ \\
\hline$X_{6}$ & 9 & 10 & 10 & 10 & $\mathbf{9 . 7 5}$ & $\mathbf{6}$ \\
\hline$X_{7}$ & 10 & 5 & 5 & 8 & $\mathbf{7 . 0 0}$ & $\mathbf{3}$ \\
\hline$X_{8}$ & 6 & 8 & 8 & 6 & $\mathbf{7 . 0 0}$ & $\mathbf{3}$ \\
\hline$X_{9}$ & 7 & 6 & 6 & 9 & $\mathbf{7 . 0 0}$ & $\mathbf{3}$ \\
\hline$X_{10}$ & 5 & 7 & 7 & 7 & $\mathbf{6 . 5 0}$ & $\mathbf{4}$ \\
\hline$X_{11}$ & 11 & 11 & 11 & 11 & $\mathbf{1 1 . 0 0}$ & $\mathbf{7}$ \\
\hline$X_{12}$ & 12 & 12 & 12 & 12 & $\mathbf{1 2 . 0 0}$ & $\mathbf{8}$ \\
\hline$X_{13}$ & 13 & 13 & 13 & 13 & $\mathbf{1 3 . 0 0}$ & $\mathbf{9}$ \\
\hline
\end{tabular}

Comparing the pairs of the rationality of alternatives, the matrix $Z$ was formed. In the matrix, one means that the option, in which it is located is more rational than the one in the column it contains. 0 means that either the option is not more rational, or its rationality is the same (Table 7).

Table 7. Matrix Z

\begin{tabular}{|c|c|c|c|c|c|c|c|c|c|c|c|c|c|c|c|}
\hline Alternatives & $X_{1}$ & $X_{2}$ & $X_{3}$ & $X_{4}$ & $X_{5}$ & $X_{6}$ & $X_{7}$ & $X_{8}$ & $X_{9}$ & $X_{10}$ & $X_{11}$ & $X_{12}$ & $X_{13}$ & $\sum \boldsymbol{P}$ \\
\hline$X_{1}$ & - & 0 & 0 & 0 & 1 & 1 & 1 & 1 & 1 & 1 & 1 & 1 & 1 & $\mathbf{9}$ \\
\hline$X_{2}$ & 0 & - & 0 & 0 & 1 & 1 & 1 & 1 & 1 & 1 & 1 & 1 & 1 & $\mathbf{9}$ \\
\hline$X_{3}$ & 0 & 0 & - & 0 & 1 & 1 & 1 & 1 & 1 & 1 & 1 & 1 & 1 & $\mathbf{9}$ \\
\hline$X_{4}$ & 1 & 1 & 1 & - & 1 & 1 & 1 & 1 & 1 & 1 & 1 & 1 & 1 & $\mathbf{1 2}$ \\
\hline$X_{5}$ & 0 & 0 & 0 & 0 & - & 1 & 0 & 0 & 0 & 0 & 1 & 1 & 1 & $\mathbf{4}$ \\
\hline$X_{6}$ & 0 & 0 & 0 & 0 & 0 & - & 0 & 0 & 0 & 0 & 1 & 1 & 1 & $\mathbf{3}$ \\
\hline$X_{7}$ & 0 & 0 & 0 & 0 & 1 & 1 & - & 1 & 1 & 1 & 1 & 1 & 1 & $\mathbf{8}$ \\
\hline$X_{8}$ & 0 & 0 & 0 & 0 & 1 & 1 & 1 & - & 1 & 1 & 1 & 1 & 1 & $\mathbf{8}$ \\
\hline$X_{9}$ & 0 & 0 & 0 & 0 & 1 & 1 & 1 & 1 & - & 1 & 1 & 1 & 1 & $\mathbf{8}$ \\
\hline$X_{10}$ & 0 & 0 & 0 & 0 & 1 & 1 & 0 & 0 & 0 & - & 1 & 1 & 1 & $\mathbf{5}$ \\
\hline$X_{11}$ & 0 & 0 & 0 & 0 & 0 & 0 & 0 & 0 & 0 & 0 & - & 1 & 1 & $\mathbf{2}$ \\
\hline$X_{12}$ & 0 & 0 & 0 & 0 & 0 & 0 & 0 & 0 & 0 & 0 & 0 & - & 1 & 1 \\
\hline$X_{13}$ & 0 & 0 & 0 & 0 & 0 & 0 & 0 & 0 & 0 & 0 & 0 & 0 & - & 0 \\
\hline$\sum N$ & 1 & 1 & 1 & 0 & 8 & 9 & 6 & 6 & 6 & 7 & 10 & 11 & 12 & \\
\hline
\end{tabular}

The last column of the matrix was obtained by summing the relative rationality values of each option. The last row of the matrix $Z$ was obtained by summing up vertically.

Borda method was used to evaluate the last column of the matrix $Z$. The most rational value had the highest score. The received priority line was as follows: $X_{4} \succ X_{1}=X_{2}=X_{3} \succ X_{7}=X_{8}=X_{9} \succ X_{10} \succ X_{5} \succ X_{6} \succ X_{11} \succ X_{12} \succ X_{13}$.

Using the Copeland method, a rational option was selected from the sum of rationality minus the number on the last line. The best value was the highest. The received priority line was as follows: $X_{4} \succ X_{2}=X_{3} \succ X_{1} \succ X_{7}=X_{8}=X_{9}$ $\succ X_{10} \succ X_{5} \succ X_{6} \succ X_{11} \succ X_{12} \succ X_{13}$. 


\section{Conclusions}

Game theory is superior to other methods because of its accuracy and comparison of methods. It allows to quickly and effectively identify and apply the most effective option. However, it is a knowledge-intensive process that requires a lot of work and preparation. Based on the selected alternatives and assessment criteria, an initial task table was created specifying the data used for the analysis and evaluation. The study used the game theory rules and several calculation methods, namely, empirical Bayes, Wald's rule, Savage criterion, and Laplace's method. Borda method demonstrated that the most rational alternative was $X_{4}$. The Copeland method resulted in the same best alternative, i.e. $X_{4}$, which was silicate blocks and stone-wool thermal insulation. Based on the criteria, all calculations unambiguously determined $X_{4}$ as the leading solution compared to other alternatives. This result was also corroborated by calculations. The second place was shared by $X_{1}$ (porous concrete blocks and stone-wool thermal insulation, $X_{2}$ (clay blocks and stone-wool thermal insulation) and $X_{3}$ (clay blocks and stone-wool thermal insulation), all of which had very similar results.

\section{References}

Barough, A. S., Shoubi, M. V., \& Skardi, M. J. E. (2012, October). Application of game theory approach in solving the construction project conflicts. Procedia - Social and Behavioral Sciences, 58, 1586-1593. https://doi.org/10.1016/j.sbspro.2012.09.1145

Bishop, C. M. (2005). Neural networks for pattern recognition. Oxford: Oxford University Press.

Borda, J. C. (1781). Memoire sur les Election au scrutiny. Histoire de l'Academie Royale des Sciences, Paris.

Fishburn, P. (1971). A comparative analyses of group decision methods. Behavioral Science, 16(6), 538-544. https://doi.org/10.1002/bs.3830160604

Harrel, F. E. Jr. (2001). Regression modeling strategies. New York: Springer-Verlag. https://doi.org/10.1007/978-1-4757-3462-1

Hwang, C. L., \& Yoon, K. (1981). Multiple attribute decisions making - methods and application. Berlin: Springer-Verlag. https://doi.org/10.1007/978-3-642-48318-9

Kendall, M. G. (1970). Rank correlation methods (4 ${ }^{\text {th }}$ ed.). London: Griffin.

MacKay, J. C. D. (2003). Information theory, inference and learning algorithms. Cambridge: Cambridge University Press.

Madurika, H. K. G. M., \& Hemakumara, G. P. T. S. (2015). GIS based analysis for suitability location finding in the residential development areas of greater Matara region. International Journal of Scientific \& Technology Research, 4(8), 96-105.

Medineckienè, M., Turskis, Z., Zavadskas, E. K., \& Folke, B. (2015). Multi-criteria decision-making system for sustainable building assessment/certification. Archives of Civil and Mechanical Engineering, 11-18. https://doi.org/10.1016/j.acme.2014.09.001

Medineckienè, M., Turskis, Z., Zavadskas, E. K., \& Tamošaitienè, J. (2010, May 19-21). Multi-criteria selection of the one flat dwelling house, taking into account the construction impact on environment. In P. Vainiūnas \& E. K. Zavadskas (Eds.), $10^{\text {th }}$ International Conference "Modern Building Materials, Structures and Techniques": Selected papers (vol. 1, pp. 455-460). Vilnius: Technika.

Peldschus, F. (2008). Experience of the game theory application in construction management. Technological and Economic Development of Economy, 14(4), 531-545. https://doi.org/10.3846/1392-8619.2008.14.531-545

Savage, L. J. (1951). The theory of statistical decision. Journal of the American Statistical Association, 46, 55-67. https://doi.org/10.1080/01621459.1951.10500768

Ustinovičius, L., Zavadskas, E. K., \& Podvezko, V. (2007). Application of a quantitative multiple criteria decisions making MCDM1 approach to the analysis of investments in construction. Control and Cybernetics, 36(1), 251-268.

Zavadskas, E. K., Kaklauskas, A., \& Banaitienè, N. (2001). Multi-criteria analysis of the building life process. Vilnius: Technika.

Zavadskas, E. K., Kaklauskas, A., Turskis, Z., \& Tamošaitienė, J. (2008). Selection of the effective dwelling house walls by applying attributes values determined at intervals. Journal of Civil Engineering and Management, 14(2), 85-93. https://doi.org/10.3846/1392-3730.2008.14.3

Zavadskas, E. K., Karablikovas, A., Malinauskas, P., Mikša, P., Nakas, H., \& Sakalauskas, R. (2006). Technology of construction processes. Vilnius: Technika.

Zavadskas, E. K., Peldschus, F., \& Kaklauskas, A. (1994). Multiple criteria evaluation of projects in construction. Vilnius: Technika.

Zavadskas, E. K., Šimkus, J. R., Sakalauskas, R., \& Nakas, H. (2000). Building construction technology: A handbook for higher education. Vilnius: Alma littera. 